\title{
Effects of Aerobic Exercise and Weight Training-Aerobic towards Physical Fitness of Elderly Hajj Candidates
}

\author{
Yudik Prasetyo ${ }^{\#}$, Muchsin Doewes", Noer Rahma" and Sapja Anantanyu" \\ \# Post Graduate Studies, Universitas Sebelas Maret, Surakarta, Indonesia \\ E-mail: ${ }^{1} y u d i k @ s t u d e n t . u n s . a c . i d,{ }^{2}$ mdoewes2000@yahoo.com, ${ }^{3}$ noerrachma55@gmail.com, ${ }^{4}$ sap_anan@staff.uns.ac.id
}

\begin{abstract}
Hajj pilgrims have been considered as activities which involve $70 \%$ of physical activity and the remaining $30 \%$ is nonphysical spiritual worship. Good physical fitness is indispensable in order to run all of the series of activities in the Hajj properly. Physical fitness pilgrims in Indonesia are generally still in the category of moderate. Improved fitness with the selection and conduct appropriate training models, will be one of the important and strategic efforts to solve the various conditions encountered in preparing pilgrims of elderly. The purpose of this study are; (1) identify and assess differences in the effect of aerobic exercise and aerobic-weight training combination towards the physical fitness of elderly pilgrims; (2) identify and assess differences in the effect of high and low motivation in influencing the physical fitness of elderly pilgrims, (3) identify and assess the interaction between exercise (aerobic and aerobic- weight training exercise combination) and high and low motivation towards physical fitness of elderly pilgrims. This study is an experimental study which is designed using $2 \times 2$ factorial. The sampling technique is purposive sampling, with a sample of 80 elderly pilgrims. Data analysis techniques are based on Prerequisite Test which use normality, homogeneity, box tests and hypothesis test which use multivariate analysis of variance (MANOVA). The results show that there is a very significant effect of aerobic exercise and weight-aerobic training towards physical fitness of the elderly pilgrims, i.e. it can be seen that the value of $0.000<0.01$. There are also significant differences of physical fitness of elderly pilgrims between high and low motivation, i.e. it can be seen that the value of $0.043<0.05$. Finally, there is no correlation on both exercise (aerobic and weight-aerobic training) and motivation (high and low) to the physical fitness of elderly pilgrims, ie it can be seen that the value of $0.524<0.05$.
\end{abstract}

Keywords — hajj pilgrims; physical fitness; aerobic exercise; weight trainning.

\section{INTRODUCTION}

The Hajj is the fifth pillar of Islam and an obligation and a duty for those able to travel to the Baitullah, able to finance, knowledge, physical and spiritual health. Therefore, physical and spiritual capabilities are one of the eligible requirements for the hajj (istithoah) based on the results of a medical examination as part of the organization of the Hajj. Implementation of the pilgrimage aims to provide guidance, services and the best protection for the pilgrims so that it can fulfill its worship in accordance with the teachings of Islam [1]. The organization of the Hajj, as mandated in Indonesian Law No. 13 Year 2008 on Hajj, aims to provide guidance, services, and the best protection for the pilgrims so that pilgrims can perform the worship in accordance with the teachings of Islam, and for this purpose, the Government is obliged to provide guidance, care, and protection by providing administrative services, guidance pilgrimage, accommodation, transportation, healthcare, security, and other things needed by pilgrims [2].

Indonesia is a country with a majority Muslim population, activities of the Hajj are $70 \%$ of physical activity and the remaining $30 \%$ is non-physical spiritual worship, as well as the majority of pilgrims who ranged from older adults to elderly. Whole body cells start to degenerate function that will result in a decline in cardiorespiratory endurance, flexibility, muscular strength, muscular endurance, coordination and balance, as well as obesity. Good physical fitness is indispensable in order to run all of the series of activities in the Hajj properly and can become a proper pilgrim. In order to achieve a good physical condition means it must have a good physical fitness [3].

Hajj activities that require physical conditions are describe as follows: (1) ranging departure from the house with enough stock weight, (2) plane approximately 9 hours, (3) walk from boarding/apartment or boundary entry of vehicles into a Mosque area, in the Medina (the Nabawi Mosque) perform Arbain prayers, namely the obligatory prayer 40 times following the main pilgrims without interruption even once, (4) from Medina to Mecca to travel by bus for approximately 9 hours (the distance between Medina-Mecca is $400 \mathrm{Km}$ ), (5) arrived in Mecca, leading to the Masjidil Haram to work with the Tawaf around the Kaaba seven times round, (6) carry out the obligatory 
prayers in the Masjidil Haram, the distance from boarding/apartment about $1 \mathrm{Km}$, by walking, (7) Sa'i, walking from the hills of Safa to Marwah 7 times $(7 \times 420$ meters = $2.9 \mathrm{KM}$ ), (8) leave for Arafah to do wukuf for one day and one night, (9) then go to Mina and stay at Muzdalifah for throwing Jumroh Aqabah at least 7 items. The distance between tents and Jamarat is approximately 4.5 KM [4].

Hajj pilgrims in Indonesia are the largest in the world. It is based on the fact that Indonesia has the largest Muslim population of the world. While pilgrims quota in each country is 1: 1000 of the total number of Muslims in that country. Therefore, if the Muslim population in Indonesia reached 211 million, then the number of pilgrims in Indonesia is 211.000 people, where it consists of 194.000 regular and 17.000 special hajjs. This does not mean that the Indonesian pilgrims who wish to perform the pilgrimage only 211.000, if allowed, may be more than 2 million pilgrims who want to Hajj. This is proven by the pilgrims who sign up in 2012 will be able to set off 12 years from now, with a waiting list Indonesian pilgrims reached 1.9 million people [5]. Queues hajj now that has reached 12 years, when people sign up at age 40 years, it will be set off when the age was 52 years, a span of 12 years, many health changes that will happen to pilgrims, especially disorders of cardiovascular disease (cause of largest death of pilgrims Hajj in 2011 (49.70\%). That condition when associated with levels of health and fitness is still lacking, it has a significant correlation, where efforts to increase physical fitness through exercise fitness program, will be one of the efforts that are important and strategic to overcome the various conditions encountered in preparing pilgrims.

Physical fitness pilgrims Indonesia is generally still in the category of fair. The measurement results of physical fitness pilgrims was carried out by the Ministry of Health of Indonesia in 2012 with a sample of 397 prospective pilgrims (6 regional) gained $25.7 \%$ in the poor category, $58.4 \%$ adequate, and $7.3 \%$ Good. In 2013 with a sample of 306 prospective pilgrims (4 regions) earned 36\% less, 59\% adequate, and 5\% better [6]. In 2014, a research of physical fitness level on special pilgrims in Yogyakarta, with a sample of 159 people has been conducted. The results show that 69 people in the poor category, while 84 people in moderate categories, and 6 in good categories. Based on those results of the related measurements, pilgrims who have physical fitness in enough categories and less, should be fostered to undergo regular exercise, for at least 6 months before departure. It is expected the pilgrims really prepared physically and mentally to undergo the pilgrimage, since it is well known that the Hajj requires a healthy physical strength in addition to the mental and spiritual preparedness.

Another issue of concern is the model of physical fitness exercise performed by pilgrims still very minimal and the results are not satisfactory, the training models such as gymnastics Hajj. Research conducted by Ningsih and Junaidi [3], using a sample of pilgrims residing in Cengkareng and Tangerang, aged between 30-50 years and do not have any specific complaints (coronary heart disease, asthma, and hypertension), and have been through inspection. The sample consisted of a given treatment group exercises during the hajj \pm 6 weeks ( $11 \frac{1}{2}$ months $)$. Before the training is given, first carried out the examination and measurement of vital signs cardiorespiratory endurance, then given exercises Hajj and at the end of the training period is measured cardiorespiratory endurance to determine whether or not changes to increase cardiorespiratory endurance after doing gymnastics Hajj. The final conclusion is that the hajj exercises can affect the increased cardiorespiratory endurance pilgrims on non-high risk significantly with the value of $\mathrm{P}(0000)$. The results can be seen statistically significant, but the views from the daily exercise rarely achieved the target zone which has been determined. The most basic things, the failure in the target zone is the duration of the exercise itself that is too short for aerobic gymnastics [7]. Therefore, it is necessary a further research on the hajj exercise or aerobic exercises that are suitable for improving the physical fitness of pilgrims, particularly the elderly. To increase physical fitness through exercise, there are various references that can be accessed as above [8]. While this model of physical fitness exercises are often used by the pilgrims as a reference is the book "Pedoman Pembinaan Kebugaran Jasmani Jemaah Haji bagi Petugas Kesehatan di Puskesmas" issued from The Indonesian Ministry of Health 2009 [2]. The exercise is aerobics and brisk. However, this book is still general and not specifically provides solutions in solving problems. While in Mecca, pilgrims must carry heavy suitcases, which contained luggage. Pilgrims who have good muscle fitness levels, will be able to support the implementation of worship Hajj. Since the beginning of pilgrims would be great if it can do weight training so that their muscles become strong. By looking at the various phenomena above relates on morbidity, mortality and its causes, as well as the fitness level that is still in the category of fair and less, it would require a study that examines the differences in the effect of aerobic exercise and a combination of aerobic exercise-weight training on physical fitness pilgrims the elderly, so expect pilgrims can perform the pilgrimage independently and become a pilgrim accepted by Allah SWT.

The rest of this paper is organized as follow. Section 2 presents the proposed method of this research. Section 3 describes results and following by discussion. Finally, section 4 concludes this research.

\section{MATERIAL AND METHOD}

This research is experimental research design used is a 2 $\times 2$ factorial [9]. The research design used in this study can be simply described in Table 1 . The population of this research is all elderly pilgrims in Yogyakarta on the list of pilgrims in 2015 amounted to 732 people. The sampling technique is purposive sampling. The number of samples taken in this study are 80 elderly pilgrims, so that each group of 20 people. The inclusion criteria is elderly people aged 60-70 years in both men and women, Par-Q \& You worthy, on EKG (Electro Cardio Graph) there are no abnormalities of the heart, there are no degenerative disease, systolic blood pressure $\leq 160 \mathrm{mmHg}$ and diastolic $\leq 100 \mathrm{mmHg}$, and are willing to sign or thumbprint on informed consent.

Exclusion criteria are elderly people who refused to follow the Physical Fitness exercise (aerobic exercise and a combination of aerobic exercise-weight training), trained elderly, based on history and medical records, there are 
diseases or disorders of the spine and experienced immobilization. Physical examination and diagnostic EKG (Electro Cardio Graph) there are abnormalities of the heart. Instruments used include measurement of fitness in the elderly form, sphygmomanometer, EKG (Electro Cardio Graph) and stethoscope are already in calibration, stopwatch, ruler, mat, mineral water bottle $600 \mathrm{cc}$, elastic, chest number, whistle, flag start and finish.

TABLE I

DESIGN OF FACTORIAL EXPERIMENTS $2 \times 2$

\begin{tabular}{|c|c|c|}
\hline & \multicolumn{2}{|c|}{ Physical Fitness Training Model (A) } \\
\hline $\begin{array}{c}\text { Motivation } \\
\text { Levels }(\mathrm{B})\end{array}$ & $\begin{array}{c}\text { Aerobic Exercise } \\
\left(\mathrm{A}_{1}\right)\end{array}$ & $\begin{array}{c}\text { The combination of Aerobic } \\
\text { Exercise-Weight Training }\left(\mathrm{A}_{2}\right)\end{array}$ \\
\hline High $\left(\mathrm{B}_{1}\right)$ & $\mathrm{A}_{1} \mathrm{~B}_{1}$ & $\mathrm{~A}_{2} \mathrm{~B}_{1}$ \\
\hline Low $\left(\mathrm{B}_{2}\right)$ & $\mathrm{A}_{1} \mathrm{~B}_{2}$ & $\mathrm{~A}_{2} \mathrm{~B}_{2}$ \\
\hline \multicolumn{3}{|c|}{ Dependent variable: Physical fitness } \\
\hline
\end{tabular}

$\mathrm{A}_{1} \mathrm{~B}_{1}=$ Treatment of aerobic exercise with high motivation.

$\mathrm{A}_{1} \mathrm{~B}_{2}=$ Treatment of aerobic exercise with low motivation.

$\mathrm{A}_{2} \mathrm{~B}_{1}=$ The treatment combination of aerobic exercise-weight training with high motivation.

$\mathrm{A}_{2} \mathrm{~B}_{2}=$ The treatment combination of aerobic exercise-weight training with low motivation.

Primary data collection techniques in the quantitative study conducted using questionnaires or enclosed questionnaire, which is a technique of data collection is done by providing a set of written questions that had been prepared in advance to respondents to answer. In addition to using the enclosed questionnaire, the data collected are also using the test measurements. Test measurement using the 1 Miles Walking Test, Sit and Reach Test, Sit-ups, push-ups, BMI and WHR to determine the level of physical fitness of elderly pilgrims.

Data analysis techniques are used by (1) Test Prerequisite using normality test, homogeneity, box test and (2) Test the hypothesis using multivariate analysis (MANOVA).

\section{RESULTS AND DISCUSSION}

This section present the obtained results and following by discussion.

\section{A. Average Delta Overall}

The results of average delta of each group given a combination of aerobic exercise and aerobic exercise-weight training with high motivation and low in each group can be seen in the Table 2 as follow.

TABLE II

THE TEST RESULTS OF AVERAGE DELTA OVERALL

\begin{tabular}{|c|c|c|c|c|c|}
\hline \multirow{2}{*}{\multicolumn{2}{|c|}{ Dependent Variable }} & \multicolumn{5}{c|}{ Groups } \\
\cline { 3 - 7 } \multicolumn{2}{|c|}{} & A1B1 & A1B2 & A2B1 & A2B2 \\
\hline \multicolumn{2}{|c|}{ Heart-lung endurance } & -1.94 & -1.32 & $\mathbf{- 2 . 0 8}$ & -1.81 \\
\hline \multicolumn{2}{|c|}{ Flexibility } & 2.07 & 1.47 & $\mathbf{2 . 4 8}$ & 2.23 \\
\hline \multirow{2}{*}{$\begin{array}{c}\text { Muscle } \\
\text { fitness }\end{array}$} & Sit-up & 6.45 & 4 & $\mathbf{9 . 6 5}$ & 7.6 \\
\cline { 2 - 6 } & Push-up & 5.8 & 5.45 & $\mathbf{9 . 3}$ & 8.35 \\
\hline \multirow{2}{*}{$\begin{array}{l}\text { Body } \\
\text { composition }\end{array}$} & BMI & $\mathbf{- 1 . 6 1}$ & -0.58 & -1.47 & -1.26 \\
\cline { 2 - 6 } & WHR & -0.02 & 0 & $\mathbf{- 0 . 0 4}$ & -0.02 \\
\hline
\end{tabular}

Based on the measurement results in Table 2 above in all categories can be seen that there is an increase in each of the dependent variable seen from a value of average delta shows positive figures, except for the variable resistance pulmonary heart, and body composition (BMI, WHR) shows negative number means decreasing. Results of workout motivation before and after treatment in each group can be seen in the Table 3 as follow.

TABLE III

EXERCISE MOTIVATION DATA DESCRIPTION IN EACH TREATMENT GROUP

\begin{tabular}{|c|c|c|c|}
\hline Groups & Pre test & Post Test & Gains \\
\hline A1B1 & 99,15 & 112,05 & 12,9 \\
\hline A1B2 & 68,95 & 101,6 & 32,65 \\
\hline A2B1 & 99,6 & 114,6 & 15 \\
\hline A2B2 & 68,6 & 103,55 & 34,95 \\
\hline
\end{tabular}

Based on the measurement results in Table 3 above four groups, all of them experienced an increase in the average value of between pre-test and post-test on exercise motivation variable. This is evident from a average value of post test is greater than the average value of pre test.

\section{B. Prerequisites Test}

To test whether the results of the descriptive analysis above significant or not, then the next will test the significance of which is also a hypothesis test. Before testing the hypothesis, then the prerequisite test analysis carried out as follows:

\section{1) Normality test}

Normality test is done to test whether the variables analyzed have distributed data distribution is normal or not. Normality test data is done using the Kolmogorov-Smirnov $Z$. The reading of the results of the data is said to be normal if $p$ value (Sig.) $>0,05$. Normality test results comprising normality test results in data group A1B1, normality test results in data group $\mathrm{A} 1 \mathrm{~B} 2$, normality test results in data group $\mathrm{A} 2 \mathrm{~B} 1$, and normality test results in data group A2B2 are respectively shown in the Tables $4,5,6$, and 7 as follow.

TABLE IV

NORMALITY TEST RESULTS IN DATA GROUP A1B1

\begin{tabular}{|c|c|c|c|c|}
\hline \multicolumn{2}{|r|}{ Variables } & $\mathrm{KS}$ & Sig. & Information \\
\hline \multirow{2}{*}{ Pre test } & $\begin{array}{l}\text { Heart-lung } \\
\text { endurance }\end{array}$ & 1.001 & 0.269 & Normal \\
\hline & Flexibility & 0.643 & 0.802 & Normal \\
\hline \multirow{4}{*}{ Normal } & $\begin{array}{l}\text { Muscle fitness (Sit- } \\
\text { up) }\end{array}$ & 0.578 & 0.892 & Normal \\
\hline & $\begin{array}{l}\text { Muscle fitness } \\
\text { (Pu\$h-up) }\end{array}$ & 0.949 & 0.328 & Normal \\
\hline & $\begin{array}{l}\text { Body composition } \\
\text { (BMI) }\end{array}$ & 0.695 & 0.720 & Normal \\
\hline & $\begin{array}{l}\text { Body composition } \\
\text { (WHR) }\end{array}$ & 1.069 & 0.203 & Normal \\
\hline \multirow{4}{*}{ Post test } & $\begin{array}{l}\text { Heart-lung } \\
\text { endurance }\end{array}$ & 1.150 & 0.142 & Normal \\
\hline & Flexibility & 0.914 & 0.374 & Normal \\
\hline & $\begin{array}{l}\text { Muscle fitness (Sit- } \\
\text { up) }\end{array}$ & 0.763 & 0.606 & Normal \\
\hline & $\begin{array}{l}\text { Muscle fitness } \\
\text { (Push-up) }\end{array}$ & 0.669 & 0.762 & Normal \\
\hline
\end{tabular}




\begin{tabular}{|l|l|c|c|c|} 
& $\begin{array}{l}\text { Body composition } \\
\text { (BMI) }\end{array}$ & 0.618 & 0.839 & Normal \\
\cline { 2 - 4 } & $\begin{array}{l}\text { Body composition } \\
\text { (WHR) }\end{array}$ & 1.104 & 0.175 & Normal \\
\hline
\end{tabular}

TABLE V

NORMALITY TEST RESULTS IN DATA GROUP A1B2

\begin{tabular}{|c|c|c|c|c|}
\hline \multicolumn{2}{|r|}{ Variables } & KS & Sig. & Information \\
\hline \multirow{6}{*}{ Pre test } & Heart-lung endurance & 0.908 & 0.382 & Normal \\
\hline & flexibility & 0.776 & 0.584 & Normal \\
\hline & Muscle fitness (Sit-up) & 0.808 & 0.531 & Normal \\
\hline & $\begin{array}{l}\text { Muscle fitness (Push- } \\
\text { up) }\end{array}$ & 0.603 & 0.860 & Normal \\
\hline & $\begin{array}{l}\text { Body composition } \\
\text { (BMI) }\end{array}$ & 0.406 & 0.996 & Normal \\
\hline & $\begin{array}{l}\text { Body composition } \\
\text { (WHR) }\end{array}$ & 0.623 & 0.832 & Normal \\
\hline \multirow{6}{*}{$\begin{array}{l}\text { Post } \\
\text { test }\end{array}$} & Heart-lung endurance & 0.648 & 0.795 & Normal \\
\hline & Flexibility & 0.649 & 0.793 & Normal \\
\hline & Muscle fitness (Sit-up) & 1.231 & 0.097 & Normal \\
\hline & $\begin{array}{l}\text { Muscle fitness (Push- } \\
\text { up) }\end{array}$ & 0.571 & 0.900 & Normal \\
\hline & $\begin{array}{l}\text { Body composition } \\
\text { (BMI) }\end{array}$ & 0.545 & 0.928 & Normal \\
\hline & $\begin{array}{l}\text { Body composition } \\
\text { (WHR) }\end{array}$ & 0.599 & 0.866 & Normal \\
\hline
\end{tabular}

TABLE VI

NORMALITY TEST RESULTS IN DATA GROUP A2B1

\begin{tabular}{|c|l|c|c|c|}
\hline \multicolumn{1}{|l|}{ Variables } & KS & Sig. & Information \\
\hline \multirow{5}{*}{ Pre test } & Heart-lung endurance & 0.946 & 0.332 & Normal \\
\cline { 2 - 5 } & Flexibility & 0.996 & 0.275 & Normal \\
\cline { 2 - 5 } & Muscle fitness (Sit-up) & 1.116 & 0.165 & Normal \\
\cline { 2 - 5 } & $\begin{array}{l}\text { Muscle fitness (Push- } \\
\text { up) }\end{array}$ & 0.706 & 0.702 & Normal \\
\cline { 2 - 5 } & $\begin{array}{l}\text { Body composition } \\
\text { (BMI) }\end{array}$ & 0.719 & 0.679 & Normal \\
\cline { 2 - 5 } & $\begin{array}{l}\text { Body composition } \\
\text { (WHR) }\end{array}$ & 0.524 & 0.947 & Normal \\
\hline \multirow{5}{*}{ Post test } & Heart-lung endurance & 1.346 & 0.053 & Normal \\
\cline { 2 - 5 } & Flexibility & 0.757 & 0.616 & Normal \\
\cline { 2 - 5 } & Muscle fitness (Sit-up) & 1.051 & 0.220 & Normal \\
\cline { 2 - 5 } & $\begin{array}{l}\text { Muscle fitness (Push- } \\
\text { up) }\end{array}$ & 0.955 & 0.321 & Normal \\
\cline { 2 - 5 } & $\begin{array}{l}\text { Body composition } \\
\text { (BMI) }\end{array}$ & 0.783 & 0.572 & Normal \\
\cline { 2 - 5 } & $\begin{array}{l}\text { Body composition } \\
\text { (WHR) }\end{array}$ & 0.624 & 0.830 & Normal \\
\hline
\end{tabular}

\section{2) Homogeneity test}

Homogeneity test is used to test the similar variance in observed data in each treatment group. Statistical tests that is used to test the homogeneity of variance is test- $F$, i.e. comparing the largest variance with the smallest variance.
The reading of the results of the data is said to be homogeneous if $p$ value $($ Sig.) $>0,05$. Homogeneity test results are shown in the Table 8.

TABLE VII

NORMALITY TEST RESULTS IN DATA GROUP A2B2

\begin{tabular}{|c|c|c|c|c|}
\hline \multicolumn{2}{|r|}{ Variables } & $\mathrm{KS}$ & Sig. & Information \\
\hline \multirow{6}{*}{ Pre test } & $\begin{array}{l}\text { Heart-lung } \\
\text { endurance }\end{array}$ & 1.174 & 0.127 & Normal \\
\hline & Flexibility & 1.116 & 0.166 & Normal \\
\hline & $\begin{array}{l}\text { Muscle fitness (Sit- } \\
\text { up) }\end{array}$ & 1.118 & 0.164 & Normal \\
\hline & $\begin{array}{l}\text { Muscle fitness } \\
\text { (Push-up) }\end{array}$ & 0.955 & 0.321 & Normal \\
\hline & $\begin{array}{l}\text { Body composition } \\
(\mathrm{BMI})\end{array}$ & 0.634 & 0.816 & Normal \\
\hline & $\begin{array}{l}\text { Body composition } \\
\text { (WHR) }\end{array}$ & 0.558 & 0.914 & Normal \\
\hline \multirow{6}{*}{ Post test } & $\begin{array}{l}\text { Heart-lung } \\
\text { endurance }\end{array}$ & 1.028 & 0.241 & Normal \\
\hline & Flexibility & 1.015 & 0.254 & Normal \\
\hline & $\begin{array}{l}\text { Muscle fitness (Sit- } \\
\text { up) }\end{array}$ & 0.946 & 0.332 & Normal \\
\hline & $\begin{array}{l}\text { Muscle fitness } \\
\text { (Push-up) }\end{array}$ & 0.871 & 0.434 & Normal \\
\hline & $\begin{array}{l}\text { Body composition } \\
\text { (BMI) }\end{array}$ & 0.781 & 0.576 & Normal \\
\hline & $\begin{array}{l}\text { Body composition } \\
\text { (WHR) }\end{array}$ & 0.487 & 0.972 & Normal \\
\hline
\end{tabular}

TABLE VIII

HOMOGENEITY TEST RESULTS

\begin{tabular}{|l|c|c|c|c|c|}
\hline & F & df1 & df2 & Sig. & Description \\
\hline Heart-lung endurance & 2.644 & 3 & 76 & .055 & Homogen \\
\hline Flexibility & .064 & 3 & 76 & .979 & Homogen \\
\hline Muscle fitness (Sit-up) & 1.254 & 3 & 76 & .296 & Homogen \\
\hline Muscle fitness (Push-up) & 1.042 & 3 & 76 & .379 & Homogen \\
\hline Body composition (BMI) & .874 & 3 & 76 & .458 & Homogen \\
\hline Body composition (WHR) & 1.349 & 3 & 76 & .265 & Homogen \\
\hline
\end{tabular}

\section{3) Box Test}

Box test is a requirement that must be fulfilled in the factorial analysis. Test box's test is used to test the assumptions of factorial analysis which requires that the variance matrix of dependent variable is the same (or no different). The reading of the results of the data matrix is said that the variance of the dependent variables is the same when $p$ value (Sig.) $>0.05$. Box test results on the data of this study are given in Table 9 as follow.

TABLE IX

Box TEST RESUlts

\begin{tabular}{|c|c|c|c|c|c|}
\hline Box's M & F & df1 & df2 & Sig. & Description \\
\hline 92.490 & 1.257 & 63 & 13533.793 & .083 & fulfilled \\
\hline
\end{tabular}

Based on the above table, the result Box test is used to test assumptions factorial analysis. Table 9 above shows that the value of $F$ test is 1.257 with sig 0.083 , meanwhile the value of Box's M is 92.490. Therefore the value of Sig, is greater than the value of alpha $5 \%(0.083>0.05)$ it can be concluded 
matrix variants of each dependent variable is the same, so fulfilled to meet the assumptions to test factorial.

4) Inferential statistics Under the Influence Exercise (Aerobic Exercise and Weight Training-Aerobic Combination)
The results of this analysis answer the hypothesis 1 , that there are differences in the effect of aerobic exercise and a combination of aerobic exercise-weight training on physical fitness of elderly pilgrims. The results of the inferential statistics are given in Table 10 as follows:

TABLE $X$

MulTiVARIATE TEST MODEL EXERCISE

\begin{tabular}{|c|c|c|c|c|c|c|c|}
\hline Effect & & Value & $\mathrm{F}$ & Hypothesis df & Error df & Sig. & $\begin{array}{c}\text { Partial Eta } \\
\text { Squared }\end{array}$ \\
\hline \multirow[t]{4}{*}{ Intercept } & Pillai's Trace & 1.000 & $36888.520^{\circ}$ & 6.000 & 73.000 & .000 & 1.000 \\
\hline & Wilks' Lambda & .000 & $36888.520^{\circ}$ & 6.000 & 73.000 & .000 & 1.000 \\
\hline & Hotelling's Trace & 3031.933 & $36888.520^{\circ}$ & 6.000 & 73.000 & .000 & 1.000 \\
\hline & $\begin{array}{l}\text { Roy's Largest } \\
\text { Root }\end{array}$ & 3031.933 & $36888.520^{\circ}$ & 6.000 & 73.000 & .000 & 1.000 \\
\hline \multirow[t]{4}{*}{ Model } & Pillai's Trace & .320 & $5.716^{a}$ & 6.000 & 73.000 & .000 & .320 \\
\hline & Wilks' Lambda & .680 & $5.716^{a}$ & 6.000 & 73.000 & .000 & .320 \\
\hline & Hotelling's Trace & .470 & $5.716^{a}$ & 6.000 & 73.000 & .000 & .320 \\
\hline & $\begin{array}{l}\text { Roy's Largest } \\
\text { Root }\end{array}$ & .470 & $5.716^{\circ}$ & 6.000 & 73.000 & .000 & .320 \\
\hline
\end{tabular}

a. Exact statistic

b. Design: Intercept + Model

Based on the table 10 above, the statistics obtained from several models, where the value of the sign is 0,000 . Therefore the value of Sig. less than $5 \%$ alpha $(0.000<0.05)$, it can be concluded that the first hypothesis is accepted. This means that there are differences in physical fitness when viewed from a decrease in the durability of the lung-heart, body composition (BMI), body composition (WHR) and increased flexibility, muscular fitness (sit-ups), muscular fitness (push-ups) among pilgrims elderly people who do aerobic exercise and a combination of aerobic exerciseweight training. To see the difference of each physical fitness variable, can be seen on the Table 11 as follow:

TABLE XI

PAIRWISE COMPARISON ON TRAINING MODEL

\begin{tabular}{|c|c|c|c|c|c|c|c|}
\hline \multirow{2}{*}{$\begin{array}{l}\text { Dependent } \\
\text { Variable }\end{array}$} & \multirow[b]{2}{*}{ (I) Model } & \multirow[b]{2}{*}{ (J) Model } & \multirow{2}{*}{$\begin{array}{c}\text { Mean } \\
\text { Difference (I- } \\
\text { J) }\end{array}$} & \multirow[b]{2}{*}{ Std. Error } & \multirow[b]{2}{*}{ Sig. ${ }^{a}$} & \multicolumn{2}{|c|}{$\begin{array}{l}\text { 95\% Confidence Interval for } \\
\text { Difference }^{\mathrm{a}}\end{array}$} \\
\hline & & & & & & Lower Bound & Upper Bound \\
\hline \multirow[t]{2}{*}{ BMI2 } & Aerobic & Aerobic Weight Training & .985 & .583 & .095 & -.176 & 2.145 \\
\hline & Aerobic Weight Training & Aerobic & -.985 & .583 & .095 & -2.145 & .176 \\
\hline \multirow[t]{2}{*}{ Walking2 } & Aerobic & Aerobic Weight Training & $-.675^{*}$ & .191 & .001 & -1.055 & -.295 \\
\hline & Aerobic Weight Training & Aerobic & $.675^{*}$ & .191 & .001 & .295 & 1.055 \\
\hline \multirow[t]{2}{*}{ Kelentukan2 } & Aerobic & Aerobic Weight Training & $-.600^{*}$ & .254 & .021 & -1.107 & -.093 \\
\hline & Aerobic Weight Training & Aerobic & $.600^{*}$ & .254 & .021 & .093 & 1.107 \\
\hline \multirow[t]{2}{*}{ SITUP2 } & Aerobic & Aerobic Weight Training & $-3.975^{*}$ & 1.324 & .004 & -6.610 & -1.340 \\
\hline & Aerobic Weight Training & Aerobic & $3.975^{*}$ & 1.324 & .004 & 1.340 & 6.610 \\
\hline \multirow[t]{2}{*}{ PUSHUP2 } & Aerobic & Aerobic Weight Training & $-2.900^{*}$ & .928 & .002 & -4.747 & -1.053 \\
\hline & Aerobic Weight Training & Aerobic & $2.900^{*}$ & .928 & .002 & 1.053 & 4.747 \\
\hline \multirow[t]{2}{*}{ WHR2 } & Aerobic & Aerobic Weight Training & .016 & .011 & .172 & -.007 & .038 \\
\hline & Aerobic Weight Training & Aerobic & -.016 & .011 & .172 & -.038 & .007 \\
\hline
\end{tabular}

Based on estimated marginal means

a. Adjustment for multiple comparisons: Least Significant Difference (equivalent to no adjustments).

*. The mean difference is significant at the .05 level.

\section{5) Inferential statistics by Level Motivation}

The results of this analysis answer the hypothesis 2 that there are differences in the physical fitness of elderly pilgrims between high and low motivation. The results of the statistics are given in Table 12 as follow: 
TABLE XII

MULTIVARIATE TEST MOTIVATION

\begin{tabular}{|c|c|c|c|c|c|c|c|}
\hline Effect & & Value & $\mathrm{F}$ & Hypothesis df & Error df & Sig. & $\begin{array}{c}\text { Partial Eta } \\
\text { Squared }\end{array}$ \\
\hline \multirow[t]{4}{*}{ Intercept } & Pillai's Trace & 1.000 & $36258.396^{\mathrm{a}}$ & 6.000 & 73.000 & .000 & 1.000 \\
\hline & Wilks' Lambda & .000 & $36258.396^{\mathrm{a}}$ & 6.000 & 73.000 & .000 & 1.000 \\
\hline & Hotelling's Trace & 2980.142 & $36258.396^{\mathrm{a}}$ & 6.000 & 73.000 & .000 & 1.000 \\
\hline & Roy's Largest Root & 2980.142 & $36258.396^{\mathrm{a}}$ & 6.000 & 73.000 & .000 & 1.000 \\
\hline \multirow[t]{4}{*}{ Motivasi } & Pillai's Trace & .159 & $2.304^{\mathrm{a}}$ & 6.000 & 73.000 & .043 & .159 \\
\hline & Wilks' Lambda & .841 & $2.304^{\mathrm{a}}$ & 6.000 & 73.000 & .043 & .159 \\
\hline & Hotelling's Trace & .189 & $2.304^{\mathrm{a}}$ & 6.000 & 73.000 & .043 & .159 \\
\hline & Roy's Largest Root & .189 & $2.304^{\mathrm{a}}$ & 6.000 & 73.000 & .043 & .159 \\
\hline
\end{tabular}

a. Exact statistic

b. Design: Intercept + Motivation

Based on the Table 12, statistical results obtained from several models where the value sign is equal to 0.043 . Therefore the value of Sig. less than $5 \%$ alpha $(0.043<0.05)$, it can be concluded that the second hypothesis is accepted. This means that there are differences in physical fitness when viewed from a decrease in the durability of the lung- heart, body composition (BMI), body composition (WHR) and increased flexibility, muscular fitness (sit-ups), muscular fitness (push-ups) among pilgrims elderly people who have high and low motivation. To see the difference in the physical fitness of each variable can be seen on the Table 13 as follow:

TABLE XIII

PAIRWISE COMPARISONS ON MOTIVATION

\begin{tabular}{|c|c|c|c|c|c|c|c|}
\hline \multirow[b]{2}{*}{ Dependent Variable } & \multirow[b]{2}{*}{ (I) Motivation } & \multirow[b]{2}{*}{ (J) Motivation } & \multirow{2}{*}{$\begin{array}{c}\text { Mean } \\
\text { Difference (I- } \\
\mathrm{J})\end{array}$} & \multirow[b]{2}{*}{ Std. Error } & \multirow[b]{2}{*}{ Sig. ${ }^{a}$} & \multicolumn{2}{|c|}{$\begin{array}{l}95 \% \text { Confidence } \\
\text { Interval for Difference }^{a}\end{array}$} \\
\hline & & & & & & $\begin{array}{l}\text { Lower } \\
\text { Bound }\end{array}$ & $\begin{array}{l}\text { Upper } \\
\text { Bound }\end{array}$ \\
\hline \multirow[t]{2}{*}{ BMI2 } & High Motivation & Low Motivation & -.889 & .585 & .132 & -2.053 & .275 \\
\hline & Low Motivation & High Motivation & .889 & .585 & .132 & -.275 & 2.053 \\
\hline \multirow[t]{2}{*}{ Walking2 } & High Motivation & Low Motivation & $.401^{*}$ & .200 & .049 & .002 & .800 \\
\hline & Low Motivation & High Motivation & $-.401^{*}$ & .200 & .049 & -.800 & -.002 \\
\hline \multirow[t]{2}{*}{ Flexibility2 } & High Motivation & Low Motivation & .275 & .262 & .296 & -.246 & .796 \\
\hline & Low Motivation & High Motivation & -.275 & .262 & .296 & -.796 & .246 \\
\hline \multirow[t]{2}{*}{ SITUP2 } & High Motivation & Low Motivation & 2.375 & 1.372 & .087 & -.357 & 5.107 \\
\hline & Low Motivation & High Motivation & -2.375 & 1.372 & .087 & -5.107 & .357 \\
\hline \multirow[t]{2}{*}{ PUSHUP2 } & High Motivation & Low Motivation & 1.150 & .976 & .242 & -.792 & 3.092 \\
\hline & Low Motivation & High Motivation & -1.150 & .976 & .242 & -3.092 & .792 \\
\hline \multirow[t]{2}{*}{ WHR2 } & High Motivation & Low Motivation & -.016 & .011 & .172 & -.038 & .007 \\
\hline & Low Motivation & High Motivation & .016 & .011 & .172 & -.007 & .038 \\
\hline
\end{tabular}

Based on estimated marginal means

a. Adjustment for multiple comparisons: Least Significant Difference (equivalent to no adjustments).

*. The mean difference is significant at the .05 level.

6) Inferential statistics Based on Interaction between Exercise (Aerobic Exercise and Weight Training-Aerobic Combination) and Motivation (High and Low)

The results of this analysis can answer the hypothesis 3 that there is no interaction between exercise (aerobic exercise and weight training-aerobic combination) and motivation (high and low) on the physical fitness of elderly pilgrims is detailed in the table 14 .
Based on the Table 14 above, obtained either model (aerobic exercise and a combination of aerobic-weight training) and motivation (high and low) there is no interaction on the results of a decrease in the durability of pulmonary heart, body composition (BMI), body composition (WHR), and increased flexibility, muscular fitness (sit-ups), muscular fitness (push-ups) pilgrims elderly. This is evidenced by the acquisition Sig value of 0.524 , which is greater than $5 \%$ alpha $(0.524>0.05)$, so that the third hypothesis is rejected. 
TABLE XIV

MULTIVARIATE TEST INTERACTION MODEL WITH TRAINING MOTIVATION

\begin{tabular}{|ll|r|r|r|r|r|}
\hline Effect & & Value & F & Hypothesis df & Error df & \multicolumn{1}{l|}{ Sig. } \\
\hline Intercept & Pillai's Trace & 1.000 & $40017.372^{\mathrm{a}}$ & 6.000 & 71.000 & .000 \\
& Wilks' Lambda & .000 & $40017.372^{\mathrm{a}}$ & 6.000 & 71.000 & .000 \\
& Hotelling's Trace & 3381.750 & $40017.372^{\mathrm{a}}$ & 6.000 & 71.000 & .000 \\
& Roy's Largest Root & 3381.750 & $40017.372^{\mathrm{a}}$ & 6.000 & 71.000 & .000 \\
\hline Motivasi & Pillai's Trace & .227 & $3.482^{\mathrm{a}}$ & 6.000 & 71.000 & .004 \\
& Wilks' Lambda & .773 & $3.482^{\mathrm{a}}$ & 6.000 & 71.000 & .004 \\
& Hotelling's Trace & .294 & $3.482^{\mathrm{a}}$ & 6.000 & 71.000 & .004 \\
& Roy's Largest Root & .294 & $3.482^{\mathrm{a}}$ & 6.000 & 71.000 & .004 \\
\hline Model & Pillai's Trace & .377 & $7.168^{\mathrm{a}}$ & 6.000 & 71.000 & .000 \\
& Wilks' Lambda & .623 & $7.168^{\mathrm{a}}$ & 6.000 & 71.000 & .000 \\
& Hotelling's Trace & .606 & $7.168^{\mathrm{a}}$ & 6.000 & 71.000 & .000 \\
& Roy's Largest Root & .606 & $7.168^{\mathrm{a}}$ & 6.000 & 71.000 & .000 \\
\hline Motivasi * Model & Pillai's Trace & .068 & $.866^{\mathrm{a}}$ & 6.000 & 71.000 & .524 \\
& Wilks' Lambda & .932 & $.866^{\mathrm{a}}$ & 6.000 & 71.000 & .524 \\
& Hotelling's Trace & .073 & $.866^{\mathrm{a}}$ & 6.000 & 71.000 & .524 \\
& Roy's Largest Root & .073 & $.866^{\mathrm{a}}$ & 6.000 & 71.000 & .524 \\
\hline
\end{tabular}

a. Exact statistic

b. Design: Intercept + Motivation + Model + Motivation * Model

\section{Discussion of results of inferential statistics Based Different Influence of Aerobic Exercise and Weight Training-Aerobic Combination}

Treatment of aerobic exercise is carried out by providing treatment in the form of brisk walking exercise with a distance of $1.6 \mathrm{Km}$, repetitions per session 1-2 times, travel time 18-20 minutes, and 2-3 minutes break between sessions with the aim of improving physical fitness (heart-lung endurance, flexibility, muscular fitness, and lower body composition) pilgrims elderly. While the combination treatment of aerobic exercise-weight training is carried by giving the combination treatment of brisk walking loadexercise namely in the form of brisk walking exercise with a distance of $1.6 \mathrm{Km}$, repetitions per exercise session 1-2 times, 2-3 minutes break between sessions, a travel time of 18-20 minutes, then rest 5 minutes, then do weight training repetition eight times, set 1-2, 2 minutes recovery between sets, and the number of posts 8-10 with the aim to improve physical fitness (heart-lung endurance, flexibility, muscular fitness, and lower body composition) pilgrims elderly.

Takeshima et al [10] say that exercise technique Nordic walking/brisk walk around the park with a distance of 1.4 $\mathrm{Km}$, three times sessions per week for 12 weeks, 50-70 minutes per day (warming up 10-15 minutes, brisk walking exercise 30 minutes in the first eight weeks and 40 minutes in the end of the fourth week/week 9-12, cooling down 1015 minutes), the exercise intensity is monitored by heart rate (HR) and subjective assessment visits of personnel/respiratory frequency, supervised by a research assistant who has been formally trained, HR is measured by the monitor automatically [PL 600] (Cateye Co., Osaka, Japan) during exercise. All participants also wear an accelerometer [Kenz Lifecorder] (Suzuken Co. Nagoya, Japan) at the waist to monitor the number of steps taken during exercise. In that study, practice the technique of
Nordic/brisk compared with a regular walking with distance, frequency of exercise, the same exercise time indicates that in all groups occur an improvement of physical fitness, but brisk walking appeared provide the greatest benefit for the improvement of physical fitness overall as shown by the increase in heart-lung endurance, strength and flexibility.

This study shows that the differences in models of aerobic exercise and a combination of aerobic exercise-weight training can give effect to the heart-lung endurance, flexibility, muscular fitness (sit-ups, push-ups), and body composition (BMI, WHR). Based on the analysis MANOVA column training models using four statistical models 1) Pillai's Trace, 2)Wilks' Lambda, 3) Hotelling's Trace dan 4) Roy's Largest Root, obtained significance value of 0.000 , less than $0.05(\mathrm{p}<0.05)$, so that means there are significant differences between the models of aerobic exercise and a combination of aerobic exercise-weight training to increase heart-lung endurance, flexibility, muscular fitness (sit-ups, push-ups), and body composition (BMI, WHR).

Improved results in this study occurred because of the influence of exercise performed regularly three times a week and performed for eight weeks. Brisk walking by administering progressively increased the training load using 65-80\% of DJM intensity, number of sessions: 1-2 sessions, and recovery: 2-3 minutes. It shows that the actual exercise brisk walking is done with the right dose of exercise will be able to give effect to the health improvement of physical fitness components. Lee Tsui - Er (2013: 1) in research that aims to determine the effect of aerobic exercise for 12 weeks and the perception of health-related physical fitness and exercise behavior in middle age and elderly. Sample is taken by purposive sampling, for the elderly above 55 years in a community is selected as samples, tests of physical fitness (BMI, 3 -min step test, 1-min sit-ups, and sit-and-reach), and surveys (questionnaires exercise behavior before and after the intervention). The results shows that (1) drop in 
blood pressure of men and women achieve a significant difference $(p<05)$, (2) increase in heart-lung endurance, muscular fitness, and flexibility of achieving a significant difference $(\mathrm{p}<05)$ and BMI were not significant, and (3) effects on exercise behavior does not reach a significant difference $(\mathrm{p}<05)$, but the frequency of exercise, items, and increased exercise period.

American College of Sports Medicine (ACSM), which held a workshop "Exercise and Physical Activity for the Elderly" highlights that pillar exercise program for the elderly should be two modalities of exercise: 1) aerobic exercise dan 2) weight training. It is known that both the exercise can improve physical fitness and health-related factors in elderly [11]. The positive benefits of aerobic exercise are widely accepted, and the importance of weight training in the elderly population is also becoming increasingly provides a clear advantage. Decreased muscle strength by 15 percent per decade after age 50, and 30 percent per decade after the age of 70 years. This is especially of sarcopenia (loss of muscle mass), and occurs to a greater extent in women than men. Results from the Framingham study showed that 45 percent of women older than 65 years, and 65 percent over 75 years to lift $10 \mathrm{lb}$. in weight training can increase 25 to 100 percent or more, so be an advantage in increasing strength in older people [12].

Research conducted by Kitamura, et al. [13] with elderly subjects aged 65-73 years is treated workout. The combination of exercise consists of hydraulic resistance training and aerobic exercise, aerobic dance or bicycling. Session of aerobic exercise and resistance training sessions are placed alternately. Subjects do in each session and move to the next session every 30 seconds, with a pause of 10 seconds marked by music and announcements verbally. Weight training is done on the same machine resistance. Hydraulic resistance machines do not require changes in load resistance, so endurance and aerobic exercise can be easily combined. Heart rate during exercise is measured by the combination of heart rate monitor (ACCUREX plus, Polar Electro, Finland). In the combination group aerobic exercise and endurance, muscle strength increases as the progress of the exercise and endurance exercise intensity increased by $30 \%$ to $60 \%$ of one repetition maximum number of repetitions and the average is 10-15 times for 30 seconds. Park, et al. [14] says that a combination of aerobic exercise such as running with an intensity of $40 \%-75 \%$ MHR and weight training in the form of an arm curl, leg curl, leg extension, squats, chest press, low back, shoulder press, lat pulldown, back extensions and sit-ups with an intensity of $60 \%-70 \% 1$ RM, 3 sets of 8-10 repetitions and can significantly increase grip strength $(\mathrm{p}<0.05)$, push-up ( $\mathrm{p}$ $<0,05)$, and maximum oxygen intake (VO2 max $)(\mathrm{p}<0,01)$.

Improved results in this study occurred because of the influence of exercise performed regularly three times a week and performed for eight weeks. The combination of brisk walking exercise-load by administering progressively increased the training load using the intensity of $65-80 \%$ of DJM, number of sessions: 1-2 sessions, the number of posts: 8-10 post, and recovery: 2-3 minutes. It shows that in fact the combination of brisk walking-load exercise performed with the right dose of exercise will be able to give effect to the health improvement of physical fitness components.
Wilson M. De Moraes, et all (2012) says that the training program is conducted with a frequency of 2 times a week, for a period of 12 weeks. Training takes \pm 60 minutes, consists of: warm-up followed by stretching \pm 10 minutes, core drills (35 to 40 minutes) consists of: a 20 minute walk with the rest of the time used to dance, and strength training with dumbbells, and cooling down by 10 minutes of stretching. Sessions conducted with moderate intensity, giving the results compared with prior training for systolic and diastolic values decreased by $3.6 \%$ and $1.2 \%$, respectively $(\mathrm{p}<0.001)$, Body mass index is reduced by $1.1 \%$ $(p<0.001)$, and peripheral blood glucose is reduced by $2.5 \%$ $(\mathrm{p}=0.002)$. There are improvements in all domains of physical fitness: muscle strength (chair-stand test and elbow flexor test; $\mathrm{p}<0.001$ ), static equilibrium (unipedal stance test; $\mathrm{p}<0.029$ ), aerobic capacity (stationary gait test); $\mathrm{p}<0.001$ ), except for versatility (sit and reach test).

The difference between aerobic exercise and a combination of aerobic-weight training to increase endurance heart-lung, flexibility, muscular fitness (sit-ups, push-ups), and a decrease in body composition (BMI, WHR) is shown on the mean difference and the results Confidence Interval for Differences in Table 11. From the analysis in Table 11, it can be concluded that aerobic exercise can make greater contributions to the improvement of heart-lung endurance than aerobic-exercise combination of weight training. While the model of aerobic-exercise combination of weight training can make greater contributions to the improvement of increased flexibility and muscle fitness (situps, push-ups) than the model of aerobic exercise. However, there is no difference in yield reduction in body composition (BMI, WHR) through the provision of training using a combination of aerobic exercise and weight training aerobic exercise.

Bojan, et al [15] says that the composition of the body is one of the components of physical fitness, and refers to the components that make up the body's tissues, usually used as an indicator is the percentage of fat tissue and lean body. People who are not active is one of the main causes of the increase in body fat. Subjects of the study were aged 55 to 85 years. Results of the analysis indicated that the greatest positive effect on changes in body composition is by doing a combined exercise program. Based on the analysis of research, duration of exercise at least 12 weeks, with three or four training sessions per week. Intensity resistance exercise should be increased to $1 \mathrm{RM} 80 \%$. Each exercise should be performed 3 sets, and repetitions 8-12. In the exercise training intensity $\pm 80 \%$ HRmax, with an average of 60 minutes of exercise each session. Results of research conducted for the composition of the body is decreased, but not significant yet. According to research conducted Jorgić Bojan, then to obtain a significant influence on changes in body composition of elderly, by giving treatment time of at least 12 weeks.

Physiologically, the elderly pilgrims who sustained an active exercise after this treatment will certainly benefit a lot. According to research conducted Kuntaraf [16] showed a significant relationship between the people who are actively engaged with the inactivity for a heart attack. Number of deaths caused by heart attacks five times greater in people whose are not actively engaged than people who are active. 
With physical exercise can cause blood vessels to become wider, even in case of deep vein thrombosis, then the practice for a long time can spur the growth of new capillary blood vessels around blocked blood vessels [17]. The flow of new blood vessels that causes the heart to still get the oxygen supply.

Improving the ability of sit-ups and push-ups on the elderly pilgrims, also proved that the increased ability of muscle work. The ability is due to the physiological changes that occur in the neuromuscular system (muscle hypertrophy, and deployment of the motor unit is growing). The size of muscle fitness depends on the size of the muscle fibers, and the number of nerve fibers that supply the muscle fibers. Muscle response from weight training, in addition to increased muscle mass, as well as neural adaptation. It is caused by a process of "learning" which is located in the motor cortex of the brain by stimuli of motion repetitively through a number of repetitions, a variety of loading and movement patterns.

\section{Results Discussion of inferential statistics Based Motivation Differences}

Based on the analysis MANOVA using four statistical models 1) Pillai's Trace, 2)Wilks' Lambda, 3) Hotelling's Trace dan 4) Roy's Largest Root, obtained a significance value of 0.043 , less than $0.05(\mathrm{p}<0.05)$; so that means there are significant differences of high and low motivation towards increased heart-lung endurance, flexibility, muscular fitness (sit-ups, push-ups), and a decrease in body composition (BMI, WHR).

Differences in high and low motivation towards increased durability heart-lung, flexibility, muscular fitness (sit-ups, push-ups), and a decrease in body composition (BMI, WHR) is shown on the mean difference and the results Confidence Interval for Differencea in Table 13, it can be concluded that high motivation can make greater contributions to the improvement of heart-lung endurance than the low motivation. However, there is no different about high motivation and low motivation in generating a decrease in body composition (BMI), body composition (WHR), and the increased flexibility, muscular fitness (sit-ups), muscular fitness (push-ups).

Motivation is one of the psychological aspect that is instrumental to its ability to show its full potential, and to achieve optimal results. Motivation makes a person feel happy engaged in activities related to these fields, and choose to make a profit and satisfaction. Strong motivation indicates that the person is embedded within a strong impetus to be able to do something. The motivation of elderly pilgrims can be used as a benchmark level of seriousness and willingness pilgrims in following aerobic exercise and weight training-aerobic combination.

Motivate someone to start the exercise, the best way can be achieved by focusing on individual goals, issues and barriers to exercise. Including strategy "phase change" model; individual behavior and active lifestyles [18]. To improve long-term adherence levels of exercise; the dose should be simple exercise, fun, and geared to the health needs of individuals, provide reinforcement faith and purpose [9]. Elderly pilgrims aerobic exercise group interested in the training, as brisk walking is considered easy to do and have a clear objective which is to improve the physical fitness. In addition, interest in the elderly pilgrims for a brisk walk perceived lack of bodily injury. The benefits for the elderly pilgrims that the body feels fresh, not easy lethargic, not easily tired, very good in weight control, and more stamina. At the time of waking up in the morning, they also feel light.

Extrinsic motivation is an impulse that comes from outside the individual that causes people to participate in sports. This impulse may come from instructors, friends, exercise programs, and infrastructure. Elderly pilgrims in the aerobic exercise group is already familiar with the movement of the brisk walk, but they do not know the right exercise program such as: training must be systematic (a process that is done in a planned exercise repeatedly and progressively increase the intensity / load, and starts from the simple to the more complex), regular (brisk walk needs physical or mental regularly performed 3 times per week, can help the work of the heart is pumping faster to increase blood circulation throughout the body, so that the physical fitness increases ), measured (measurable exercise consider a variety of factors, ranging from the age, condition and physical ability, the quality of the organs, and intensity), and continuous (brisk walking exercise is done in accordance exercise program, do not go around will be one round and then stop, but is performed continuously) [19]. With a good description of the researchers and instructors so that pilgrims elderly are more motivated to do the exercises.

In the group of weight- training aerobic combination exercise, there are still many elderly pilgrims who do not know about the movement and the benefits of the combination of exercise. So that the post-test, because already know and feel the benefits, to increasing the motivation. Therefore already get benefits, elderly pilgrims want this program can be run in the following years. In addition, elderly pilgrims also said that there needs to be a dormitory setting up physical fitness pilgrims, the place can be named "Asrama Bugar Hajï".

Elderly pilgrims is interested in following the combination of aerobic-weight training exercise, because they feel this type of training as a novelty. The combination of aerobic-weight training exercise previously thought by the pilgrims elderly that exercise should be done at the Fitness Center, apparently after they follow can be done in the indoor or outdoor. Moreover, the movement conducted also interesting, so that pilgrims elderly getting excited. Variations of movement and creative instructors in delivering training programs to make pilgrims comfortable and not bored in practice.

Elderly pilgrims aerobic-weight training exercise group like to follow a combination of exercise in order to improve health and fitness. They feel that the older, the body feels fatigue and muscles more wrinkles. Moreover, fat in the body too much, it makes the elderly pilgrims move to follow the practice. Truly appearance felt by pilgrims as: which is usually use the car to anywhere for fear of colds, after follow the combination of aerobic -weight training exercise, they dare to wear his own motorcycle. At the time of treatment sometimes less favorable weather (drizzle or rain), but to feel the benefits, they remain excited about coming to practice. There used to be that feeling sleeplessness and 
appetite is not good, after following a combination of aerobic weight-training exercise, can sleep early / felt well and eat more tasteful.

High motivation will form a good attitude toward their favorite activity. Maslow mentions motivation as the need to gain self-esteem, its manifestation is the need for achievement and the need to succeed in their activities. Implementation of the exercise is the higher need for achievement, the more enthusiasm for the practice [20]. They follow a program like this for the first time. In the running exercise, the elderly pilgrims can follow the exercises with ease and fun. By feeling the benefits, they finally called to the pilgrims who could join the others for training. In the exercise, the instructor can explain it well and give the right examples of exercises, so that the elderly pilgrims eager to follow the exercise and feel cared.

Motivation of pilgrims in the combination of aerobicsweight training group, even though the result is a high increase in training, but should still be a concern. The hope is that the elderly pilgrims in following the practice is not solely for the preparation of the pilgrimage in Mecca, but elderly pilgrims willing and able to do the physical fitness exercises until back to Indonesia, as well as their healthy conditions in groups or independently.

\section{E. Results Discussion of inferential statistics Interactions Based Training Motivation}

According to understand dualism between body and mind are clearly different. The body is simply a realistic complex object while the mind is in the abstract and mental dimensions. The mind does not depend on the material body, because when the body does not work anymore minds can continue to exist independently. It can be used as an example: someone who has a strong desire and passionate to exercise 3 times per week, it will not get the fitness results if no action/moving. While people who are mediocre, but direct action / move, it will receive feedback on their body.

Based on the results of multivariate analysis in the fields of interaction model of training and motivation in Table 14, the results obtained significance value of $0.524>0.05$, so it can be interpreted that there is no interaction models of aerobic exercise and aerobic weight-training combination with high and low motivation on resistance heart-lung, flexibility, muscular fitness (sit-ups, push-ups), and body composition (BMI, WHR). The absence of these interactions, where overall the dependent variable show model line training and motivation are not mutually intersect.

The results of this study indicate that there is no interaction models of aerobic exercise and a combination of aerobicweight-training with high and low motivation on durability heart-lung, flexibility, muscular fitness (sit-ups, push-ups), and body composition (BMI, WHR ), although each (both models of training and motivation) have resulted in increased. The absence of these interactions showed that in all four treatment groups although it can have an effect on physical fitness, but the type of training and motivation is no interaction. It can be said that the pilgrims elderly people with low and high motivation, if they do not do an appropriate exercise program, it will not increase physical fitness, therefore motivation is driving people to try to establish a change in behavior. when pilgrims elderly want to increase physical fitness, the main one is to do exercise regularly.

Physiologically, regular exercise will impact directly on the muscles in the body of the elderly pilgrims, so that it becomes more active [21]. Muscle is an endocrine organ, in response to contraction to produce and release myokines, which can affect metabolism and alter cytokine production in the tissues and organs. Myokines involved in mediating the effects of the health benefits of exercise and have an important role in protection against diseases, such as heart disease, type 2 diabetes, the symptoms associated with the metabolic syndrome and cancer. It is clear that knowledge of the mechanisms by which regular exercise offers protection against chronic diseases could have implications for pharmacological. The recent identification myokines and receptors that could serve as a target for the treatment of metabolic disorders and other diseases [22]. Identified first myokine is interleukin 6 (IL-6), now known as myokine prototype, exert two effects; Local muscle as well as effects on the endocrine organs. Since the discovery of IL-6, it has been recognized skeletal muscle that has the capacity to express various myokines (See Figure 1).

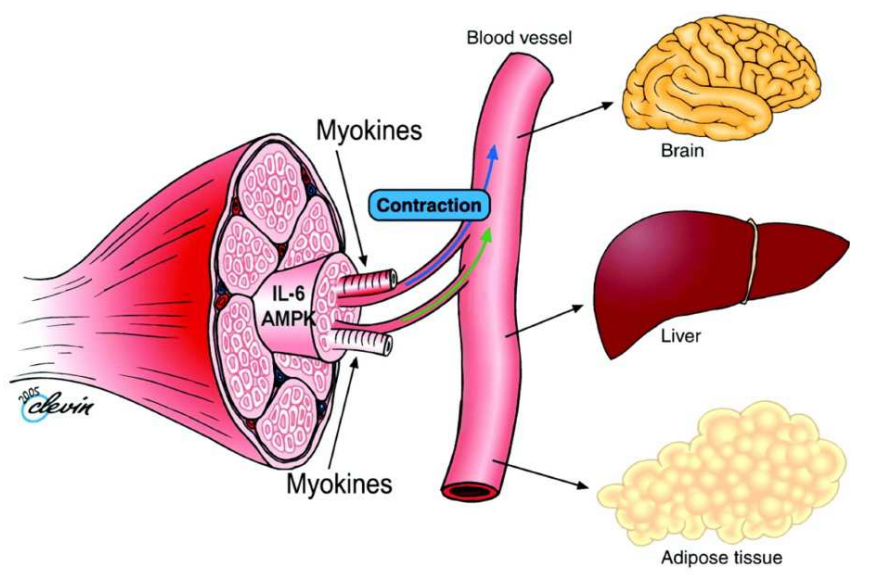

Fig. 1. Muscle Frame Removing Myokines

Pedersen Bente K. and Fischer Christian P., [22]

This cytokine genes encoding silent when the muscles relax, but quickly switched through contraction. Faster transcription level reported for all other genes in the muscle, and the amount of transcripts can increase $>100$ times. Production of IL - 6 is modulated by the availability of carbohydrates in the muscles, and IL- 6 serves as an energy sensor. Released from muscle contraction in bulk and exerts its effect on adipose tissue, stimulates lipolysis and gene transcription in abdominal subcutaneous fat.

Pedersen Hojman [23] says that exercise is associated with many metabolic benefits and health. During the exercise, cytokines and other peptides secreted by muscles that work with the potential to act locally in the muscle tissue as an endocrine or by targeting other distant organs. Although it is not exclusively secreted by muscle cells, these proteins are classified as "myokines" in the physiological context of skeletal muscle. Emerging evidence suggests that muscle-derived cytokines play an important role in mediating both acute sports metabolic changes, and changes in metabolic adaptation to next training. In response to increase insulin, glucose uptake and fatty acid oxidation in 
skeletal muscle are some of the beneficial effects of exercise performed on a regular basis, which have all been shown partly mediated by myokines [24]. Likewise, the systemic effects myokines release in response to muscle contraction is involved in various metabolic regulatory mechanisms in the medium and long term in distant organs such as the adipose tissue. Myokines is central to our understanding of crosstalk (during and after exercise between skeletal muscle and other organs) as described in Figure 2.

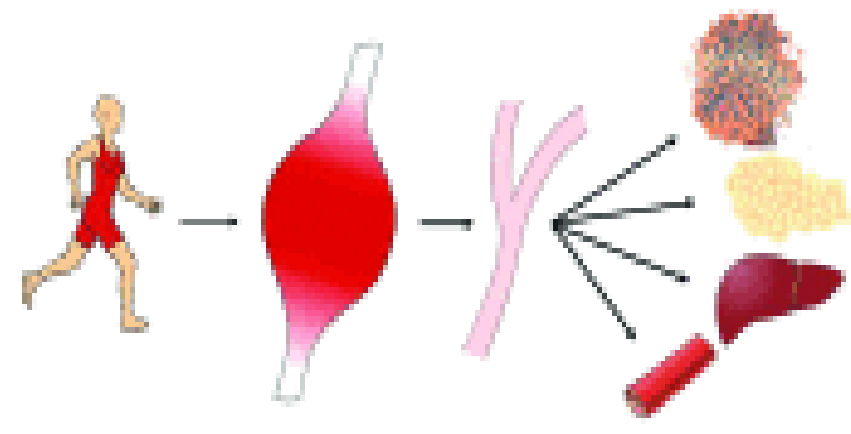

Fig. 2. Crosstalk muscles with organ Mediated by myokines Pedersen Line dan Hojman Pernille [23]

In addition to the effects of local muscles, which indirectly affects the metabolism of the whole body, myokines also been shown to act directly in distant organs when released into the systemic circulation. Again IL-6 can be used as an example. Adipose tissue IL- 6 has been shown to increase lipolysis and fatty acid oxidation, namely through induction fosfolirasi AMPK. IL-6 also increase hepatic glucose production during exercise. Interestingly, IL-6 is also believed to affect the function of the pancreas, and the products that come out of the skeletal muscle has been directly shown to increase proliferation and glucose stimulated insulin secretion from $\beta$ cells. In addition, injection of IL-6 and IL-6 levels induced by exercise, has recently been shown to stimulate the secretion of GLP-1 from intestinal $\mathrm{L}$ cells and $\alpha$ cells of the pancreas, which leads to improvements in secretion of insulin and glycaemia. Thus, skeletal muscle and pancreas act synergistically to monitor systemic glucose homeostasis, and these results suggest a role of mediation myokines in cross talk between sensitive insulin tissues.

The finding that the muscles produce and release myokines created a paradigm shift and open up horizons of science, technology, and new scientific. These findings represent a breakthrough in integrative physiology and contributes to our understanding of why regular exercise protects against a variety of chronic diseases. Thus myokine provides the conceptual basis for the underlying molecular mechanisms, for example, cross talk muscle-fat, heart muscles, muscle-pancreas, and muscle-brain [25]. Based on this, then it is clear that to improve physical fitness, the elderly pilgrims are activating skeletal muscle by doing exercises in a measured, orderly, systematic, and sustainable.

\section{CONCLUSIONS}

In this paper, a study on the effects of aerobic exercise and weight training-aerobic towards physical fitness of elderly hajj candidates has been presented. Based on the analysis and discussion of different effects of aerobic exercise and aerobic-weight training combination on physical fitness hajj candidates elderly, it can be concluded as follows: There is a significant different effect of aerobic exercise and aerobic weight-training combination towards the physical fitness of elderly pilgrims, i.e it can be seen that the sign of $0.000<0.01$. There are significant differences of physical fitness of elderly pilgrims between high and low motivation, i.e it can be seen that the sign of $0.043<0.05$. There is no interaction between exercise (aerobic and combined aerobic-weight training) and motivation (high and low) on the physical fitness of elderly pilgrims, i.e it can be seen that the sign of $0.524<0.05$.

\section{ACKNOWLEDGMENT}

This research is supported by Universitas Sebelas Maret Postgraduate Research Grant.

\section{REFERENCES}

[1] Realita Haji: Media Komunikasi Penyelenggaraan Haji dan Umrah, Edisi VII, Tahun 2012. Ibadah Haji Membutuhkan Kesehatan Yang Prima. Jakarta: Ditjen Penyelenggaraan Haji dan Umrah Kementerian Agama RI

[2] Menkes RI. 2009. Keputusan Menteri Kesehatan RI, Nomor: 442/MENKES/SK/VI/2009, tentang Pedoman Penyelenggaraan Kesehatan Haji Indonesia. Jakarta.

[3] Ningsih Ika Setia, Junaidi. 2005. Pengaruh Latihan Senam Haji Terhadap Peningkatan Daya Tahan Jantung Paru Pada Calon Jamaah Haji Non Resiko Tinggi. Jurnal Fisioterapi Indonusa Vol. 5 No. 2, Oktober 2005.

[4] Soeparman. 2004. Panduan Senam Haji; Cara bugar saat menunaikan panggilan Allah. Jakarta: Puspa Swara.

[5] Rachmadi, Anugrah. 2014. Studi Tentang Rekrutmen Tentang Calon Jamaah Haji Dalam Keberangkatan ke Saudi Arabia di Kantor Kementerian Agama Kota Samarinda. eJournal Ilmu Pemerintahan 2014, 2 (2 ): 2372 - 2386.

[6] Dirjen Bina Gizi dan KIA Kemenkes RI. 2014. Pembekalan Petugas Kesehatan dalam Pembinaan Kebugaran Jasmani Calon Jemaah Haji, Edisi Maret 2014. Jakarta.

[7] Lee Tsui - Er. 2013. Effects Of Aerobics Intervention On HealthRelated Physical Fitness And Exercise Behavior Of The MiddleAged And Elderly People. International Journal of Sport and Exercise Science 5 (1): 1-6, 2013.

[8] Mooren, Frank C., et al. "Circulating microRNAs as potential biomarkers of aerobic exercise capacity." American Journal of Physiology-Heart and Circulatory Physiology 306.4 (2014): H557H563.

[9] Creswell J. W. 2013. Research Design: Pendekatan Kualitatif, Kuantitatif, dan Mixed, Edisi III. Pustaka Pelajar.

[10] Islam Nobuo Takeshima Mohammod M., et all. 2013. Effects Of Nordic Walking Compared To Conventional Walking And BandBased Resistance Exercise On Fitness In Older Adults. Journal of Sports Science and Medicine (2013) 12, 422 - 430.

[11] Arenas Salvador Romero, et all. 2013. Impact of Resistance Circuit Training on Neuromuscular, Cardiorespiratory and Body Composition Adaptations in the Elderly. Aging and Disease, Volume 4, Number 5, October 2013.

[12] Nied Robert J., and Franklin Barry. 2002. Promoting and Prescribing Exercise for the Elderly. February1, 2002 / Volume 65, Number 3 American Family Physician.

[13] Kitamura Itsuko, et all. 2003. Effects of Aerobic and Resistance Exercise Training on Insulin Action in the Elderly. Japan: Geriatrics and Gerontology International 2003; 50-55.

[14] Park Sung-Mo,. Et all. 2015. The Effect of Combined Exercise on Health Related Fitness, Endotoxin, and Immune Function of Postmenopausal Women with Abdominal Obesity. Journal of Immunology Research. Volume 2015, article ID 830567, 8 pages.

[15] Jorgić Bojan, et all. 2011. Composition of the Elderly: a Systematic Review. Physical Education and Sport Vol. 9, No 4, Special Issue, 
2011, Pp. 439 - 453. Serbia: The Faculty Of Sport And Physical Education Niš.

[16] Kuntaraf, J. \& Kuntaraf, K. 1993. Olahraga Sumber Kesehatan. Jakarta: Indonesia Publishing House.

[17] Mann, Steven, Christopher Beedie, and Alfonso Jimenez. "Differential effects of aerobic exercise, resistance training and combined exercise modalities on cholesterol and the lipid profile: review, synthesis and recommendations." Sports Medicine 44.2 (2014): 211-221.

[18] Thompson, Paul D., et al. "ACSM's new preparticipation health screening recommendations from ACSM's guidelines for exercise testing and prescription." Current sports medicine reports 12.4 (2013): 215-217.

[19] Swift, Damon L., et al. "The role of exercise and physical activity in weight loss and maintenance." Progress in cardiovascular diseases 56.4 (2014): 441-447.

[20] Ten Brinke, Lisanne F., et al. "Aerobic exercise increases hippocampal volume in older women with probable mild cognitive impairment: a 6-month randomised controlled trial." British journal of sports medicine 49.4 (2015): 248-254.
[21] Macko, R. F., F. M. Ivey, and L. W. Forrester. "Task-oriented aerobic exercise in chronic hemiparetic stroke: training protocols and treatment effects." Topics in stroke rehabilitation (2015).

[22] Pedersen Bente K. and Fischer Christian P. 2007. Beneficial health effects of exercise - the role of IL-6 as a myokine. TRENDS in Pharmacological Sciences Vol.28 No.4.

[23] Pedersen Line dan Hojman Pernille. 2012. Muscle-to-organ cross talk mediated by myokines. Adipocyte. 2012 Jul 1; 1(3): 164-167.

[24] Wilson m. De Moraes, Pamella r. m. Souza, Mônica h. n. p. Pinheiro, Maria c. Irigoyen, Alessandra Medeiros, Marcia k. Koike. (2012). Exercise Training Program Based On Minimum Weekly Frequencies: Effects on Blood Pressure and Physical Fitness In Elderly Hypertensive Patients. ISSN 1413-3555, Rev Bras Fisioter, São Carlos. Brazil: Revista Brasileira De Fisioterapia.

[25] Pedersen Bente K. 2009. Edward F. Adolph Distinguished Lecture: Muscle as an endocrine organ: IL-6 and other myokines. Journal of Applied Physiology Published 1 October 2009 Vol. 107 no. 4, 10061014. 